Tersedia online di: http://ejournal-balitbang.kkp.go.id/index.php/JP
e-mail:jurnalpari@gmail.com
JURNAL PARI
volume 5 Nomor 1 Juli 2019
p-ISSN: 2502-0730
e-ISSN : 2549-0133

\title{
DAMPAK UNDANG-UNDANG REPUBLIK INDONESIA NOMOR 23 TAHUN 2014 TENTANG PEMERINTAHAN DAERAH TERHADAP PENGELOLAAN ARSIP DINAMIS DI BALAI KARANTINA IKAN PENGENDALIAN MUTU DAN KEAMANAN HASIL PERIKANAN SEMARANG
}

\author{
Tri Hudayanti \\ Balai Karantina Ikan Pengendalian Mutu dan Keamanan Hasil Perikanan Semarang \\ Jalan Dr. Suratmo Nomor 28 Kelurahan Kembangarum Semarang 50183, Telp. 024-76671020 \\ Diterima tanggal : 28 Mei 2019 Diterima setelah perbaikan : 20 Juni 2019 \\ disetujui terbit : 9 Juli 2019
}

\begin{abstract}
ABSTRAK
Arsip adalah rekaman kegiatan/peristiwa dalam berbagai bentuk dalam media sesuai dengan perkembangan teknologi informasi dan komunikasi yang dibuat dan diterima oleh lembaga Negara, pemerintahan daeah, lembaga pendidikan, perusahaan, organisasi politik, organisasi kemasyarakatan, dan perseorangan dalam pelaksanaan kehidupan bermasyarakat, berbangsa, dan bernegara. Kegiatan Pengelolaan arsip dinamis adalah proses penciptaan, penggunaan dan Pemeliharaan, serta penyusutan arsip yang dilakukan terhadap arsip aktif, arsip inaktif dan arsip vital, secara efisien, efektif, dan sistematis. Tujuan dari artikel ini adalah untuk memberikan informasi kepada masyarakat dengan ditetapkannya Undang-Undang RI No. 23 Tahun 2014 tentang Pemerintahan Daerah, maka kegiatan pengelolaan arsip dinamis di Balai Karantina Ikan Pengendalian Mutu dan Keamanan Hasil Perikanan volumenya menjadi lebih banyak. Metode yang digunakan adalah Kuantitatif yaitu metode riset yang fokus pada penggunaan angka, tabel, grafik untuk menampilkan hasil data yang diperoleh dari Sidat (Sistim Informasi Data Statistik) yang ada pada Balai Karantina Ikan Pengendalian Mutu dan Keamanan Hasil Perkanan. Data yang dihasilkan melalui Sidat dihasilkan jumlah arsip sebelum dan sesudah adanya Undangundang Republik Indonesia Nomor 23 Tahun 2014 tentang Pemerintahan Daerah terjadi perbedaan yang signifikan, sehingga berdampak sekali pada pengelolaan arsip di Balai Karantina Ikan Pengendalian Mutu dan Keamanan Hasil Perikanan Semarang, semakin bertambahnya volume arsip maka akan berpengaruh pula dengan ketersediaan sarana dan prasarana, mengingat sarana dan prasarana di Balai Karantina Ikan Pengendalian Mutu dan Keamanan Hasil Perikanan Semarang terbatas. Kesimpulannya adalah pada Balai Karantina Ikan Pengendalian Mutu dan Keamanan Hasil Perikanan Semarang berupaya menambah sarana dan prasarana dalam pengelolaan arsip.
\end{abstract}

Kata Kunci : Dampak peralihan wewenang; Pengelolaan Arsip Dinamis

\section{ABSTRACT}

The archive is recording activities and events in various forms in media in line with the development of information technology and communication are made and received by state institutions, local government, educational institution, company, political organization, social organization and individuals in the implementation of social life national and state. The Activity of management dynamic archive is the process of creation, use and maintenance, and depreciation archive done with active archive, inactive archive and vital archive as an efficient, effective, and systematic. The purpose of this article to giving information to society with the law of the Republic of Indonesia number 23 of 2014 concerning local government, so the management activities archive dynamic in Fish Quarantine and Inspection Agency. The methods used quantitative method which is focused on numeric, table, graphic to show the result data which collected from Sidat (statistics data information system) in Fish Quarantine and Inspection Agency. Data collect through Sidat produced by archive number before and after the law of the Republic of Indonesia number 23 of 
2014 on local government is going on a significant difference, so that it will effected on archive management in Fish Quarantine and Inspection Agency Semarang. It will increase archive volume that can be effected the availability facility and infrastructure, by remembering it in Fish Quarantine And Inspection Agency Semarang. The conclusion is in Fish Quarantine and Inspection Agency Semarang attempted to improve infrastructure in archive management

\section{Keywords: The authority of transition effect; dynamic archive management}

\section{PENDAHULUAN}

Balai Karantina Ikan Pengendalian Mutu dan Keamanan Hasil Perikanan Semarang merupakan UPT (Unit Pelaksana Teknis) dari Badan Karantina Ikan Pengendalian Mutu dan Keamanan Hasil Perikanan, Kementerian Kelautan dan Perikanan Republik Indonesia, Kegiatan yang merupakan tugas pokok Karantina Ikan di Balai Karantina Ikan Pengendalian Mutu dan Keamanan Hasil Perikanan cukup banyak seperti kegiatan ekspor, impor, domestik masuk dan domestik keluar dalam satu bulan untuk kegiatan ekspor aja setiap bulan mencapai 440 kegiatan data tersebut diambil dari SIDAT (Sistem Informasi Data Statistik Semarang), dimana dalam satu kali kegiatan dapat menciptakan arsip sebanyak 20 lembar, kalo di hitung kasar setiap bulannya arsip bisa mencapai 8.800 lembar atau sama dengan $68 \mathrm{~cm}$, belum lagi untuk kegiatan operasional lain seperti Impor, Domestik Keluar dan Domestik Masuk serta kegiatan perkantoran seperti di bagian persuratan, keuangan kepegawaian, dan lainnya, yang tiap harinya menciptakan naskah dinas/arsip. Bisa dibayangkan betapa banyaknya arsip setiap bulan kita simpan, lama kelamaan akan menumpuk dan menyita tempat.

Sebagaimana diamanatkan dalam Undang-Undang Republik Indonesia No. 23 Tahun 2014 tentang Pemerintah Daerah Bagian ketiga tentang Urusan Pemerintah Konkuren Bab. IV Urusan Pemerintahan, Pasal 12 ayat 3 bagian urusan Kelautan dan Perikanan, yaitu telah terjadi perubahan wewenang Lembaga Inspeksi dan Sertifikasi dalam Penerbitan Sertifikat Kesehatan dari LPPMHP yang ada di Jawa Tengah (LPPMHP Semarang, Cilacap dan Pekalongan) di bawah Dinas Kelautan dan Perikanan Provinsi Jawa Tengah beralih ke Balai Karantina Ikan Pengendalian Mutu dan Keamanan Hasil Perikanan Semarang. Dengan adanya peralihan wewenang tersebut volume arsip yang di ciptakan semakin banyak, hal ini sangat perpengaruh pada pengelolaan kearsipan di Balai Karantina Ikan Pengendalian Mutu dan Keamanan Hasil Perikanan Semarang.

Semakin bertambahnya volume arsip yang ada di Balai Karantina Ikan Pengendalian Mutu dan Kamanan Hasil Perikanan Semarang maka akan berpengaruh terhadap ketersediaan sarana dan prasarana, serta
Sumberdaya Manusia yang mengelola arsip tersebut. Tujuan dari artikel ini adalah memberikan informasi kepada masyarakat dengan ditetapkannya Undangundang Republik Indonesia Nomor 23 Tahun 2014 tentang Pemerintahan Daerah, maka pengelolaan arsip di Balai Karantina Ikan Pengendalian Mutu dan Kamanan Hasil Perikanan Semarang menjadi lebih luas berupa dokumen

\section{TINJAUAN PUSTAKA}

Arsip adalah rekaman kegiatan atau peristiwa dalam berbagai bentuk dan media sesuai dengan perkembangan teknologi informasi dan komunikasi yang dibuat dan diterima oleh lembaga Negara pemerintah daerah, lembaga pendidikan, perusahaan, organisasi politik, organisasi kemasyarakatan dan perseorangan dalam pelaksanaan kehidupan bermasyarakat, berbangsa, dan bernegara (Peraturan Menteri Pendayagunaan Aparatur Negara dan Reformasi Birokrasi Republik Indonesia Nomor 13 Tahun 2016, tentang Jabatan Fungsional Arsiparis dan Angka Kreditnya dalam pasal 1). Kegiatan Kearsipan adalah kegiatan yang dilaksanakan dalam rangka mendukung penyelenggaraan kearsipan yang meliputi pengelolaan arsip dinamis, pengelolaan arsip statis, pembinaan kearsipan, dan pengolahan dan penyajian arsip menjadi informasi.

Kegiatan pengelolaan arsip dinamis adalah proses penciptaan, penggunaan dan pemeliharaan, serta penyusutan arsip yang dilakukan terhadap arsip aktif, arsip inaktif dan arsip vital, secara efisien, efektif, dan sistimatif. Dalam pembahasan kali ini focus pada penyusutan arsip.

Kegiatan Penyusutan Arsip adalah pengurangan arsip melalui Pemindahan arsip inaktif dari unit pengolah ke unit kearsipan, Pemusnahan arsip yang telah habis retensinya dan tidak memiliki Nilai guna lagi dan penyerahan arsip statis oleh penvipta arsip kepada lembaga kerasipan sesuai dengan Peraturan Menteri Pendayagunaan Aparatur Negara dan Reformasi Birokrasi Republik Indonesia Nomor 13 Tahun 2016, tentang Jabatan Fungsional Arsiparis dan Angka Kreditnya dalam pasal 1, karena di Balai Karantina Ikan Pengendalian Mutu dan Keamanan Hasil Perikanan Semarang merupakan UK UPT (Unit Kearsipan tingkat UPT) dimana kegiatan penyusutan 
hanya sebatas pemindahan arsip dan pemusnahan, untuk kegiatan penyerahan arsip statis akan dilaksanakan oleh UK-1 yaitu di Biro Umum Kementerian Kelautan dan Perikanan Republik Indonesia.

Implementasi Undang-Undang No. 23 Tahun 2014 tentang Pemerintah Daerah di Balai Karantina Ikan Pengendalian Mutu dan Keamanan Hasil Perikanan Semarang tentang pelayanan sertifikasi dan pemeriksaan hasil mutu perikanan yang tadinya di laksanakan di LPPMHP di bawah Dinas Kelautan dan Perikanan Provinsi Jawa Tengah, maka dengan adanya Undang-undang tersebut kewenangan dilimpahkan kepada Balai Karantina Ikan Pengendalian Mutu dan Keamanan Hasil Perikanan Semarang, sehingga mempengaruhi volume arsip di Balai Karantina Ikan Pengendalian Mutu dan Keamanan Hasil Perikanan Semarang Semarang, seperti yang diketahui untuk proses serifikasi kegiatan ekspor dan pemeriksaan laboratorium tentunya akan menciptakan banyak arsip, sehingga sangat berpengaruh pada volume arsip di Balai Karantina Ikan Pengendalian Mutu dan Keamanan Hasil Perikanan Semarang. Salah satu cara untuk mengatasi masalah bertumpuknya atau tertimbunnya arsip yang tidak berguna lagi (Badir Barthos, 2003:99), arsip yang akan disimpan adalah arsip yang memiliki nilai guna.

Menurut Barthos (2007:101), Penyusutan arsip adalah kegiatan pengurangan dengan cara :

1. Memindahkan arsip inaktif dari unit pengolah ke unit kearsipan dalam lingkungan lembaga-lembaga Negara atau badan-badan pemerintah masingmasing.

2. Memusnahkan arsip sesuai dengan ketentuanketentuan yang berlaku.

3. Menyerahkan arsip statis oleh unit kearsipan kepada arsip nasional.

Di Balai Karantina Ikan Pengendalian Mutu dan Keamanan Hasil Perikanan sudah menyusun SOP (Standar Operasional Prosedur) tentang penataan arsip aktif, penataan arsip inaktif dan penyusutan arsip, lebih jelas SOP tersebut adalah:

1. Penataan Arsip Aktif

2. Penataan Arsip Inaktif

3. Penyusutan (Pemusnahan)

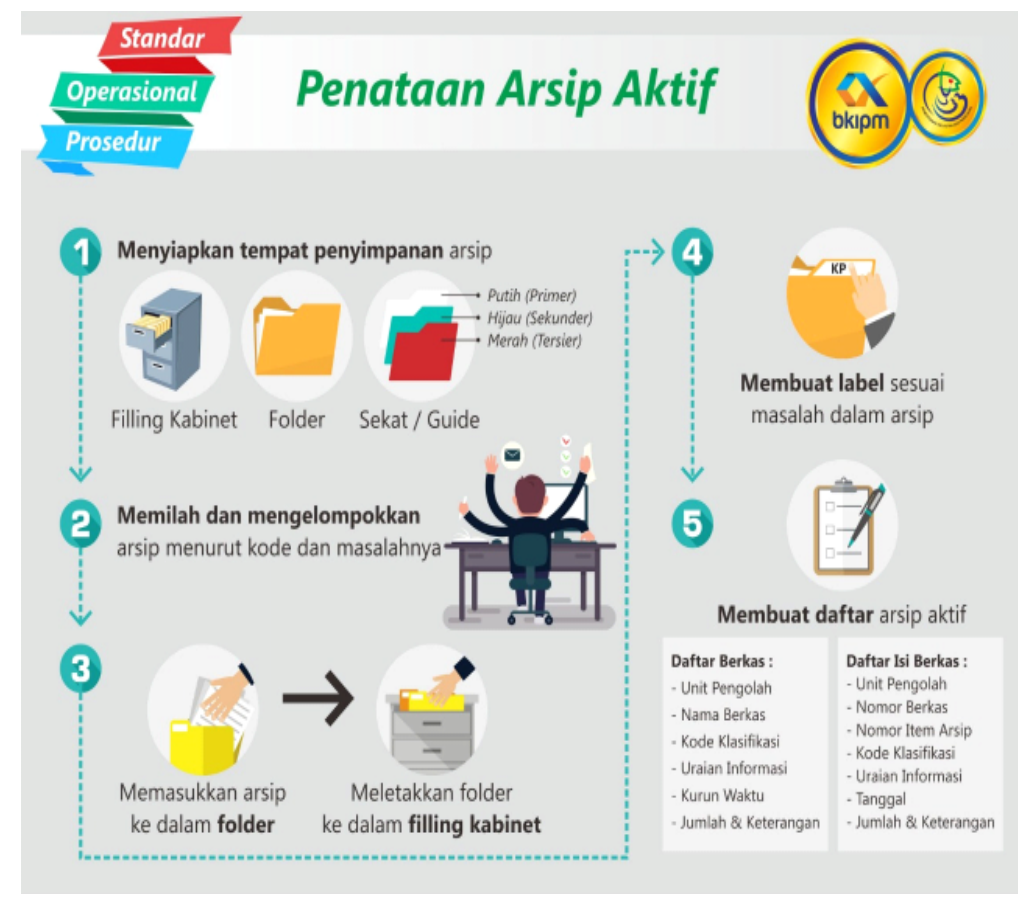

Dalam Penataan arsip aktif yang perlu diperhatikan adalah :

1. Menyiapkan tempat tempat penyimpanan arsip antara lain filling kabinet, folder dan guide/sekat, untuk guide/sekat ada 3 macam yaitu guide primer berwarna putih, guide skunder berwa hijau dan guide tersier berwarna merah.

2. Memilih dan Mengelompokkan yaitu memilih dan mengelompokkan arsip sesuai dengan kode dan masalahnya berdasarkan pada Peraturan Menteri
Kelautan dan Perikanan Republik Indonesia Nomor 67/PERMEN-KP/2016, tentang Kearsipan di Lingkungan Kementerian Kelautan dan Perikanan.

3. Memasukkan arsip ke dalam folder kemudian memasukkan kedalam lemari filling kabinet.

4. Membuat dan menempel lebel sesuai masalah dalam arsip.

5. Membuat daftar arsip aktif yang meliputi daftar berkas dan daftar isi berkas. 


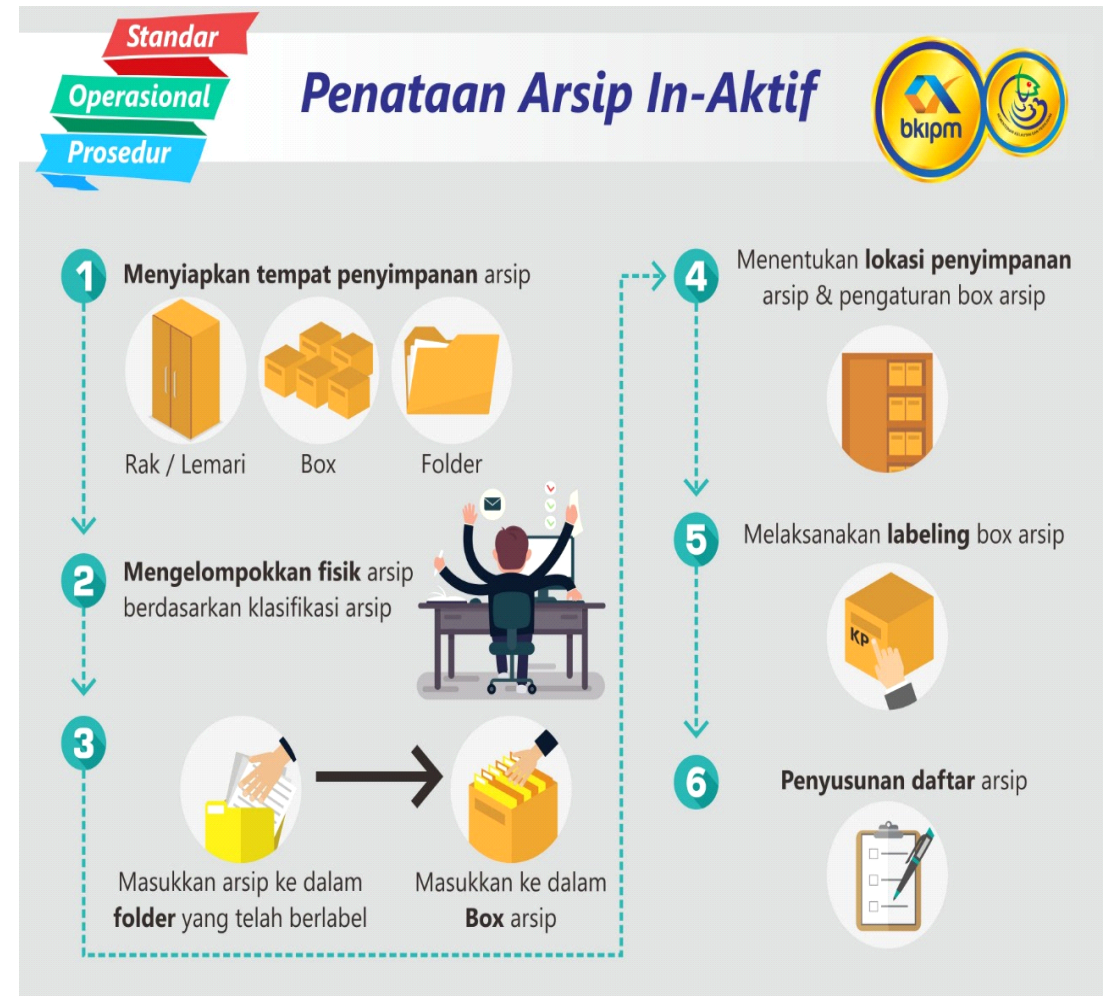

Penataan Arsip Inaktif tahapannya adalah :

3. Memasukkan arsip kedalam folder yang telah diberi lebel kemudian memasukkan ke dalam Box arsip.

1. Menyiapkan tempat penyimpanan arsip antara lain Rak/lemari arsip, boks arsip dan folder.

4. Menentukan lokasi penyimpanan arsip dan pengaturan boks arsip.

2. Mengelompokkan fisik arsip berdasarkan

5. Lebeling boks arsip. klasifikasi arsip.

6. Penyusunan daftar arsip inaktif.

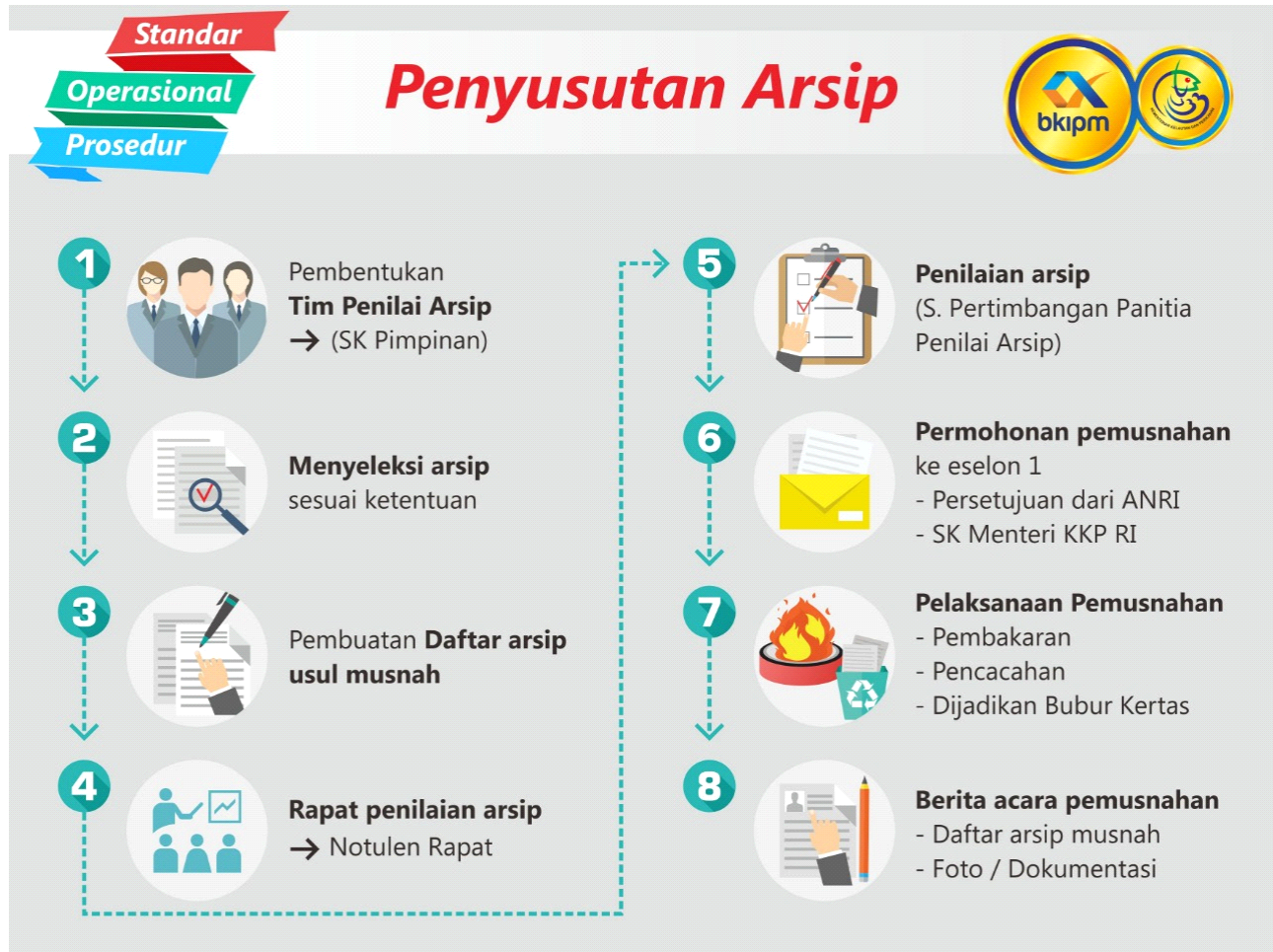


SOP selanjutnya adalah Penyusutan arsip (Pemusnahan), di Balai Karantina Ikan Pengendalian Mutu dan Keamanan Hasil Perikanan Semarang sudah setiap tahun dilakukan Pemusnahan, Semakain bertambahnya tahun kegiatan pemusnahan semakin bagus lagi dari tata cara sampai pengadministrasiannya. Mulai tahun 2018 Balai Karantina Ikan Pengendalian Mutu dan Pengelolaan Hasil Perikanan telah menetapkan standar Operasional tentang penyusutan, adapun tahapan penyusutan antara lain adalah :

1. Pembentukan Tim Penilai arsip dengan di tuangkan dalam Surat Keputusan Kepala Balai,

2. Melaksanakan Penyeleksian arsip artinya memilah mana yang benar-benar mempunyai nilai guna atau hanya sampah saja,

3. Membuat Daftar Arsip, setelah arsip selesai diseleksi kemudian dibuatkan daftar arsip sesuai dengan klasifikasinya,

4. Rapat Penilaian Arsip output dari kegiatan ini adalah terdapatnya notulen rapat,

5. Penilaian arsip yaitu menilai sesuai dengan peraturan yang berlaku dan menghasilkan surat pertimbangan panitia penilai arsip,

6. Permohonan Pemusnahan yang ditujukan kepada UK-2 yaitu Badan Karantina Ikan Pengendalian Mutu dan Keamanan Hasil Perikanan di Jakarta dengan di tembusan ke UK-1 dalam hal ini Biro Umum dan BPJ Kementerian Kelautan dan Perikanan Republik Indonesia, point 1 s.d 6 adalah syarat untuk pengajuan pemusnahan, setelah mendapatkan persetujuan dari ANRI (Arsip Nasional Republik Indonesia) kegiatan pemusnahan dilaksanakan dan kemudian pemuatan berita acara, point selanjutnya adalah pengiriman laporan pemusnahan dan berita acara ke Unit Kearsipan 1.

Keuntungan dari adanya pemindahan dan pemusnahan arsip adalah penghematan penggunaan ruang kantor, penghematan pemakaian peralatan, dan perlengkapan kearsipan, tempat arsip yang agak longgar akan memudahkan petugas bekerja dengan arsip (Amsyah 1996:104). Di Balai Karantina Ikan Pengendalian Mutu dan Keamanan Hasil Perikanan Semarang kegiatan penyusutan hanya sebatas memindahkan arsip dari pencipta arsip ke pengelola arsip dan pemusnahkan arsip.

Dalam pengelolaan arsip perlu adanya sarana dan prasarana kearsipan berupa ruang arsip dan lemari arsip. Tata ruang penyimpanan arsip inaktif pasa dasarnya dapat dibagi 2 (dua) yaitu ruangan kerja dan ruangan penyimpanan arsip inaktif. Ruangan kerja merupakan ruangan yang digunakan untukkegiatan menerima arsip yang baru dipindahkan, membaca arsip inaktif, mengolah arsip inaktif, dan memusnahkan arsip yang tidak bernilai guna. Ruang penyimpanan arsip inaktif digunakan khusus untuk menyimpan arsip sesuai dengan tipe dan medianya yang suatu saat akan dimusnahkan.

Lemari arsip digunakan untuk menyimpan arsip atau dokumen instansi. Fungsi lemari arsip sangatlah penting. Coba bayangkan jika tidak ada lemari arsip dimana kita akan menyimpan arsip-arsip penting. Lemari arsip dalam bentuk laci yang dapat ditarik keluar masuk dan terdiri dari 5 atau 6 laci yang tersusun ke bawah disebut filling cabinet. Filling cabinet ini biasanya digunakan untuk menyimpan arsip aktif, sedangkan intuk sarana penyimpanan arsip inaktif dapat digunakan lemari khusus arsip dengan mobile file mekanik atau mobile file system manual, yaitu lemari arsip yang dapat bergerak atau bergeser. Lemari ini dapat menghemat ruangan, anti rayap dan anti karat, sehingga arsip dapat tersimpan dengan aman.

Seiring waktu volume arsip di Balai Karantina Ikan Pengendalian Mutu dan Keamanan Hasil Perikanan mengalami perkembangan menjadi banyak, semakin bertambah kegiatan maka semakin cepat pula bertambahnya berkas dan arsip, dan tidak selamaya arsip akan terus berada di dalam tempat penyimpanan. Untuk mengatasi masalah tersebut diperlukan pemusnahan arsip, di Balai Karantina Ikan Pengendalian Mutu dan Keamanan Hasil Perikanan Semarang sudah dilaksanakan pemusnahan arsip setiap tahunnya dengan mengacu pada Peraturan Menteri Kelautan dan Perikanan Republik Indonesia Nomor 67/PERMEN-KP/2016 tentang Kearsipan di Lingkungan Kementerian Kelautan dan Perikanan dengan JRA (Jadwal Retensi Arsip) 2 Tahun dengan keterangan Musnah untuk arsip tindak karantina Ekspor dengan cara pembakaran dan pencacahan.

Pemusnahan dengan Jadwal Retensi Arsip merupakan suatu daftar yang berisi jenis arsip beserta jangka waktu penyimpanan dengan keterangan simpan permanen, musnah, atau dinilai kembali. Penyusutan dengan jadwal retensi arsip hendaknya tidak lepas dari tindakan menilai suatu arsip baik atas dasar jenis fisiknya. Pemusnahan arsip ini dilakukan menggunakan mesin penghancur kertas atau bias juga dengan cara dibakar sesuai dengan cara pemusnahan menurut Sukoco (2007 : 101) Penyusutan arsip dilakukan dengan cara pencacahan, dibakar, menggunakan bahan kimia dan pembuburan. Pemusnahan arsip sesuai dengan pendapat Amsyah (2001:2018), Pedoman yang dijadikan dasar seleksi adalag Jadwal Retensi. Langkah-langkah penyusutan umumnya terdiri dari seleksi, pembuatan daftar jenis 
arsip yang dimusnahkan, pembuatan berita acara pemusnahan dan pelaksanaan pemusnahan dengan disertai saksi-saksi.

\section{METOD}

Metode yang dilakukan pada artikel ini melalui pendekatan Kualitatif dengan jenis studi kasus yang memusatkan pada suatu kasus secara intensif dan rinci, artikel ini disusun dengan maksud untuk mengetahui secara mendalam kegiatan pengelolaan arsip di Balai Karantina Ikan Pengendalian Mutu dan Keamanan Hasil Perikanan Semarang sebelum dan sesudah ditetapkannya Undang-undang Republik Indonesia Nomor 23 Tahun 2014 tentang Pemerintahan Daerah dengan tujuan memberikan informasi kepada masyarakat bahwa pengelolaan arsip sangat dipengaruhi dengan volume arsip itu sendiri. Dalam artikel ini data yang diperoleh dari sumber data primer dengan melakukan wawancara kepada kepala Sub Bagian Tata Usaha sebagai pimpinan langsung kegiatan pengelolaan arsip di Balai Karantina Ikan Pengendalian Mutu dan Keamanan Hasil Perikanan Semarang. Data skunder diperoleh melalui petugas kerasipan dan operator Sidat (Sistem Informasi Data Statistik Semarang).

Analisis data dilakukan melalui pengumpulan data dari aplikasi Sidat kemudian membandingkan data fisik arsip yang dikelola oleh pengelola arsip, kemudian menilai data sesuia focus dan selanjutnya membuat kesimpulan pada masing-masing temuan focus.

\section{HASIL DAN PEMBAHASAN}

Dari tahun ke tahun volume arsip di Balai Karantina Ikan Pengendalian Mutu dan Keamanan Hasil Perikanan Semarang semakin meningkat, lebih lagi setelah berlakunya Undang-undang Republik Indonesia Nomor 23 Tahun 2014 tentang Pemerintahan Daerah mulai diberlakukan pada awal Tahun 2016 demikian yang disampaikan oleh Kepala Sub Bagian Tata Usaha Balai Karantina Ikan Pengendalian Mutu dan Keamanan Hasil Perikanan Bapak Joko Purwono, SE., MM., hal ini bisa di lihat dari kegiatan penyusutan arsip untuk setiap tahunnya, untuk sarana dan prasarana rak arsip pun dari tahun ke tahu semakin meningkat dari menggunakan rak arsip sekarang sudah menggunakan roll o'pact, dengan bertambahnya volume arsip yang dikelola, seperti di kutip dalam Peraturan Menteri Kelautan dan Perikanan Republik Indonesia Nomor 67/PERMEN$\mathrm{KP} / 2016$ tentang Kearsipan di Lingkungan KKP dahwa keuntungan penggunaan roll o'pact lebih banyak dapat menampung volume arsip yang disimpan serta perlengkapan lainnya dijamin aman, mudah diakses, dan terlindung dari hama.

Berikut data volume arsip dokumen sertifikat ekspor pada tahun 2015-2018 yang telah di himpun melalui sumber dari SIDAT (Sistem Informasi Data Statistik Semarang) :

\begin{tabular}{|c|c|c|c|c|}
\hline Tahun & 2015 & 2016 & 2017 & 2018 \\
\hline $\begin{array}{l}\text { Volume } \\
\text { Ekspor }\end{array}$ & 147 bundel & 3.246 bundel & 3.494 bundel & 5.284 bundel \\
\hline
\end{tabular}

Dari data di atas jelas terlihat volume sertifikat ekspor di tahun 2015 berjumlah 147 bundel sedangkan di tahun 2016 berjumlah 3.246 bundel, terdapat perbedaan yg signifikan dari volume Sertifikat Kesehatan ekspor yang dikelola hal ini didasari dari Surat Keputusan Kepala Badan Karantina Ikan, Pengendalian Mutu dan Keamanan Hasil Perikanan
Nomor 110/KEP-BKIPM/2015 tentang Pendelegasian Kewenangan Lembaga Inspeksi dan Sertifikasi Dalam Penerbitan Sertifikat Kesehatan yang diberlakukan per tanggal 2 Januari 2016, otomatis volume untuk arsip 2016 akan meningkat. Dari tahun ke tahun volume arsip sertifikat ekspor meningkat hal ini bisa dilihat pada grafik berikut : 

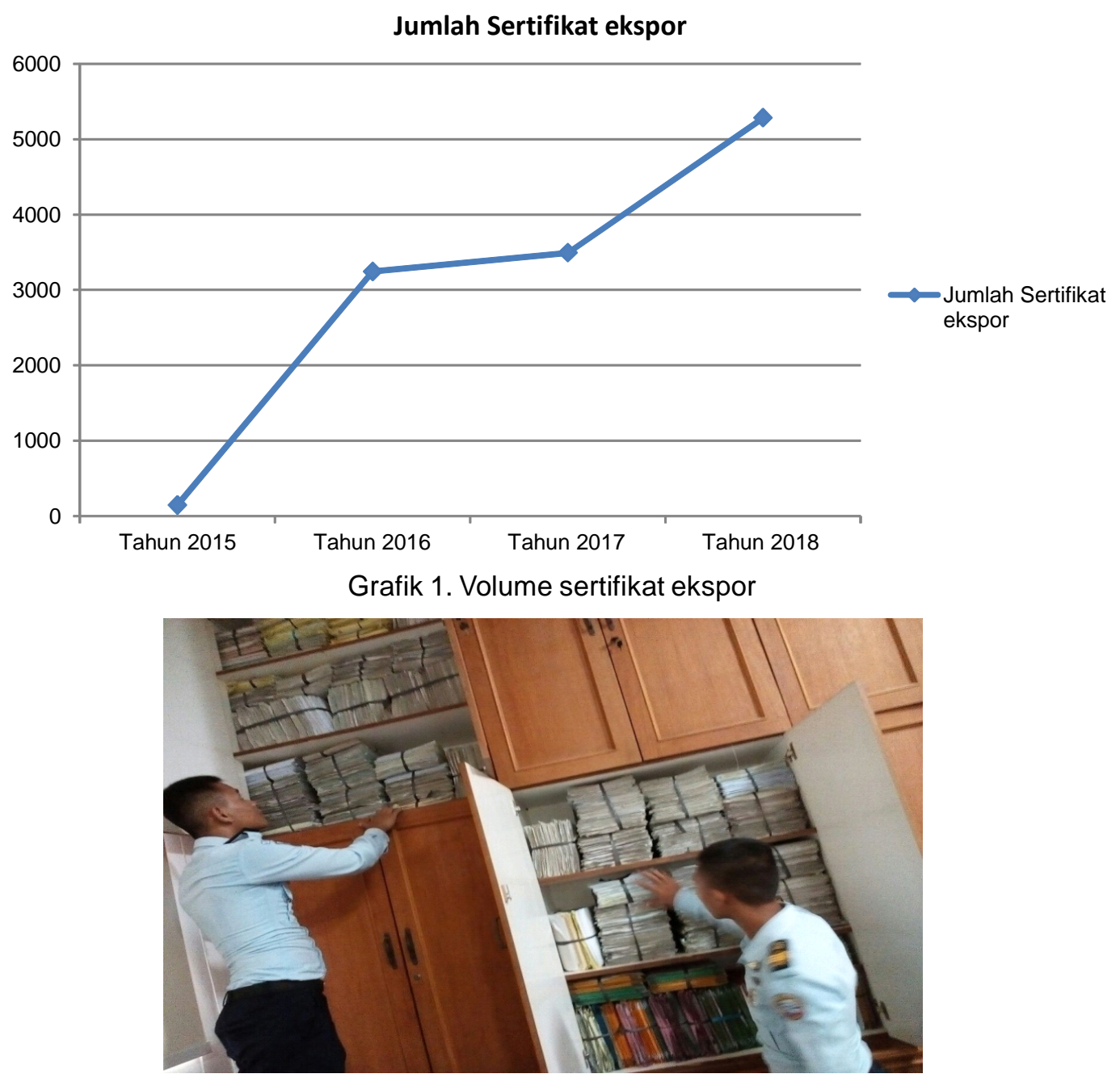

Foto 1. Penyimpanan arsip aktif sebelum pelimpahan wewenang

Terlihat jelas dalam grafik diatas peningkatan volume arsip yang dikelola di Balai Karantina Ikan Pengendalian Mutu dan Keamanan Hasil Perikanan, hal tersebut berpengaruh juga terhadap sarana dan prasarana kerasipan, dapat di lihat juga pada Foto 1 terlihat volume dan penyimpanan arsip aktif sebelum ada perpindahan wewenang, arsip sertifikat kesehatan ikan di simpan didalam lemari kayu dengan kondisi terikat sarana dan prasarana masih sederhana.

Pada Foto 2 adalah Rak arsip Penyimpanan arsip aktif yang dikelola oleh pencipta arsip di Balai Karantina Ikan Pengendalian Mutu dan Keamanan Hasil Perikanan Semarang dalam hal ini petugas pada Seksi Tata Pelayanan, yang digunakan untuk menyimpan arsip sertifikat kesehatan sebelum ada pelimpahan wewenang.

Dalam pemilihan peralatan penyimpanan arsip aktif di Balai Karantina Ikan Pengendalian Mutu dan Keamanan Hasil Perikanan semakin tahun semakin meningkat, setelah volume arsip sertifikat ekspor mulai banyak penyimpanan menggunakan boks arsip yg di tata pada rak arsip dari besi, menurut Wursanto (2004:54), rak arsip adalah sejenis almari tidak berpintu, yang merupakan rakitan dari beberapa keeping papan, kemudian diberi tiang untuk menaruh atau menyimpan berkas-berkas atau arip, dan terletak pada lantai bawah, hal ini untuk mempermudah proses pemusnahan mengingat masa retensi arsip tersebut hanya 2 (dua) tahun. 


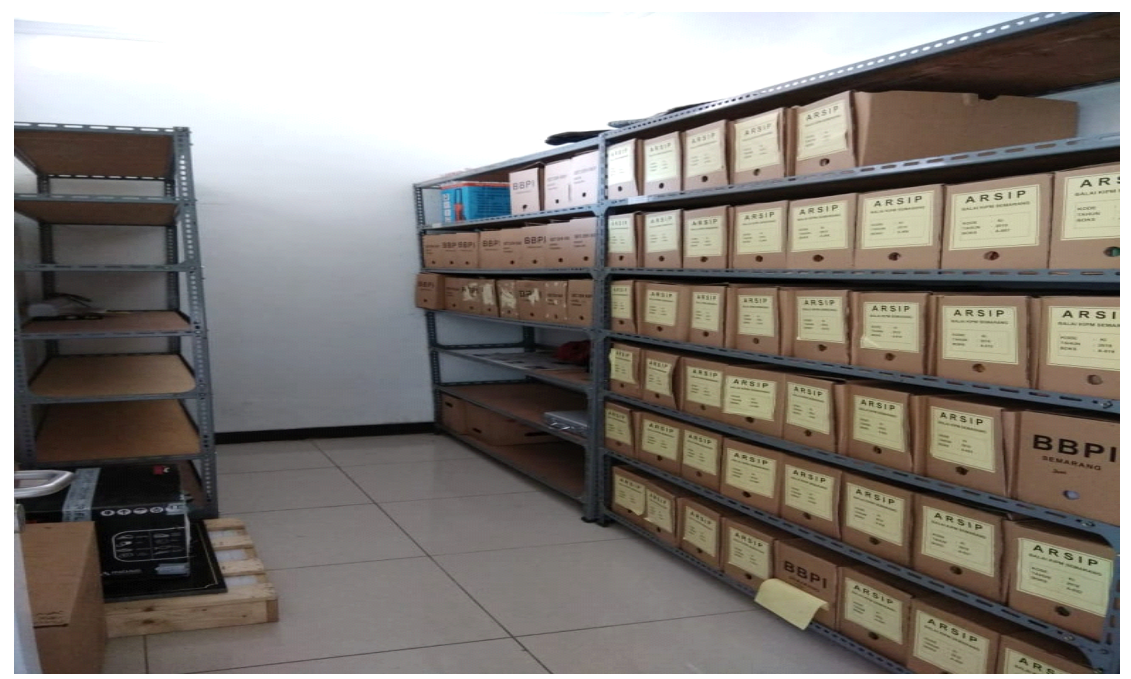

Foto 2. Penyimpanan arsip aktif sesudah ada pelimpahan wewenang

Dijelaskan lebih lanjut oleh Agus Sugiarto dan Teguh Wahyono (2005:76), dalam pemilihan peralatan yang akan dipakai dalam penyimpanan arsip terdapat beberapa criteria yang harus diperhatikan, yaitu :

a. Bentuk fisik dari arsip yang akan disimpan

b. Frekuiensi penguunaan arsip

c. Lama arsip disimpan di file antif dan file inaktif

d. Lokasi dari fasilitas penyimpanan

e. Besar ruangan yang disediakan untuk menyimpan dan kemungkinan untuk perluasannya

f. Tipe dan letak tempat penyimpanan untuk arsip inaktif g. Bentuk organisasi untuk mempertimbangkan kemungkinan perkembangan jumlah arsip yang akan disimpan

h. Tingkat perlindungan terhadap arsip yang disimpan.

Arsip sertifikat ekspor yang telah habis masa aktifnya akan dipindahkan ke ruang arsip Inaktif atau Recort Center yang di kelola oleh pengelola arsip dalam hal ini Arsiparisdi Balai Karanatina Ikan Pengendalian Mutu dan Keamanan Hasil Perikanan Semarang. Foto berikut adalah Recort Centersebelum ada pelimpahan wewenang

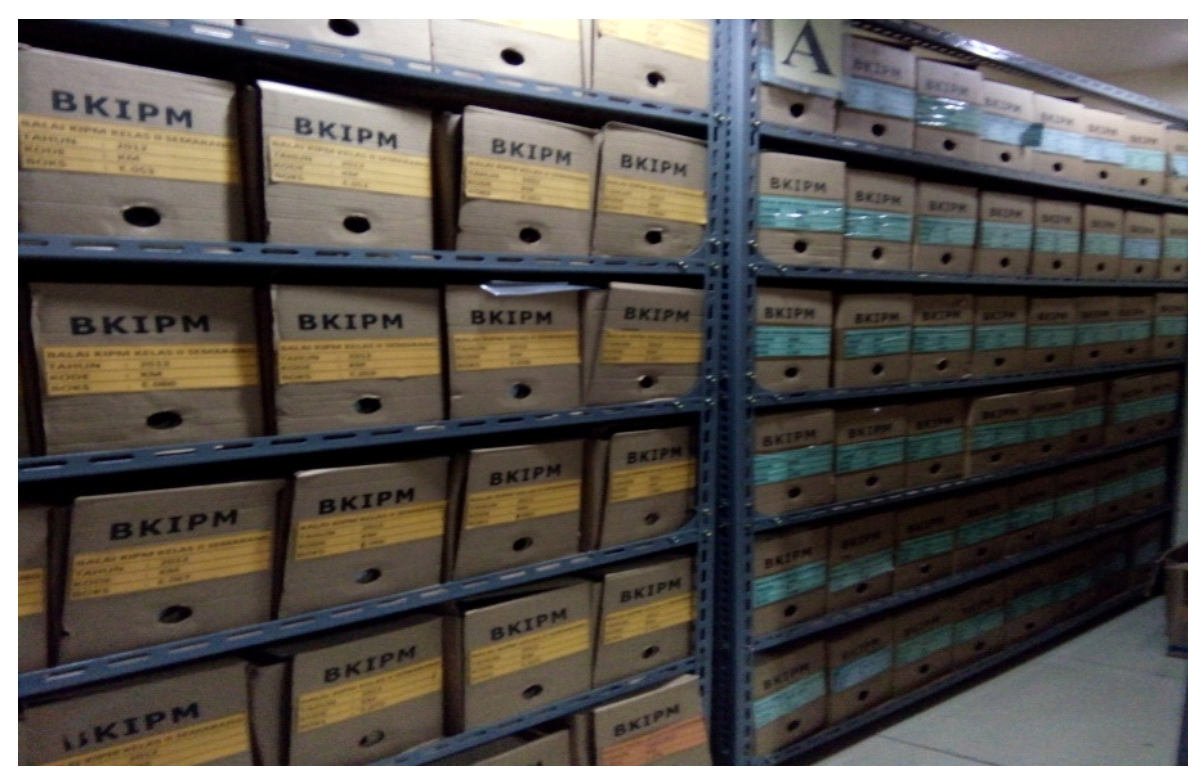

Foto 3. penyimpanan arsip Inaktif sebelum pelimpahan wewenang 
Data sertifikat yang masuk pada pengelola arsip pada tahun 2018 karena dokumen tahun 2016 masa inaktif pada tahun 2018, hal ini sesuai dengan Peraturan Menteri Kelautan dan Perikanan Republik Indonesia Nomor 67/PERMEN-KP/2016, tentang Kearsipan Di Lingkungan Kementerian Kelautan dan Perikanan, bahwa Jadwal Retensi Arsip (JRA) Dokumen Tindak Karantina Ikan 2 Tahun dengan keterangan musnah.

Foto 3 , merupakan penyimpanan arsip inaktif sertifikat kesehatan sesudah berlakunya undang- undang tersebut, tempat penyimpanan lebih rapi dengan menggunakan boks arsip, pada waktunya berpindah ke inaktif akan mempermudah Arsiparis dalam mengelola arsip.

Foto 4 adalah Rollpag, yaitu lemari arsip besi untuk penyimpanan arsip inakti, dengan adanya pelimpahan wewenang dari pemerintahan daerah ke Balai KIPM Semarang yang notabennya pemerintah pusat, semakin maju lagi sarana dan prasarana di Balai Karantina Ikan Pengendalian Mutu dan Keamanan Hasil Perikanan.

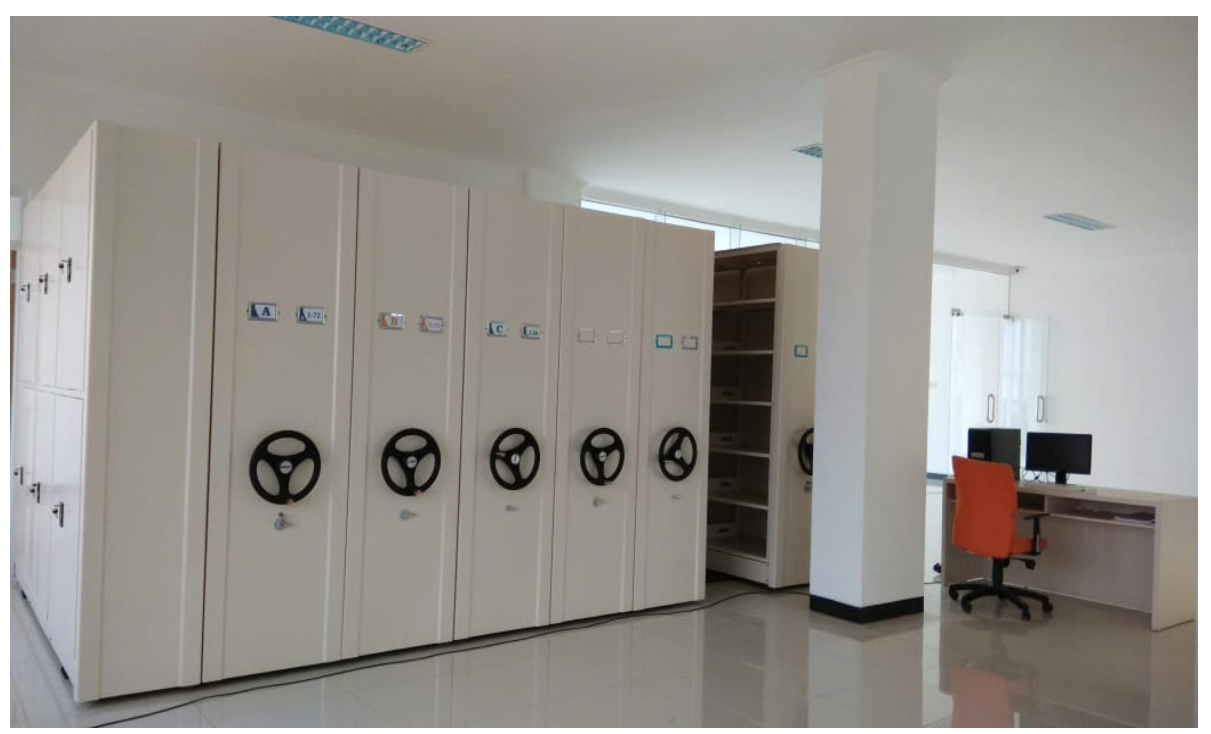

Foto 4. Rollpag tempat penyimpanan arsip Inaktif

\section{KESIMPULAN}

Kesimpulan dari hasil dan pembahasan artikel ini bahwa dampak Undang-Undang Republik Indonesia No. 23 Tahun 2014 tentang Pemerintahan Daerah adalah sebagai berikut :

1. Pada Tahun 2016 Terjadi Pelimpahan Pendelegasian wewenang lembaga inspeksi dan sertifikasi dalam penerbitan sertifikat kesehatan kesehatan ikan khususnya sertifikat ekspor di Balai Karantina Ikan Pengendalian Mutu dan Keamanan Hasil Perikanan Semarang, hal ini sesuai dengan Surat Keputusan Kepala Badan Karantina Ikan Pengendalian Mutu dan Keamanan Hasil Perikanan Nomor : 110/KEP-BKIPM/2015 tanggal 30 November 2015 tentang Pencabutan atas Keputusan Kepala Badan Karantina Ikan Pengendalian Mutu dan Keamanan Hasil Perikanan Nomor 115/KEP-BKIPM/2013 tentang Pendelegasian Kewenangan Lembaga Inspeksi dan Sertifikasi dan Penerbitan Sertifikat Kesehatan.
2. Volume arsip meningkat dari tahun 2016 sampai dengan 2018 sehingga arsip yang dikelola oleh petugas pengelola arsip bertambah, terlihat hasil sertifikasi ekspor yang tercipta adalah : Tahun 2015 mencapai 147 sertifikat, Tahun 2016 mencapai 3.246 sertifikat, Tahun 2017 mencapai 3.494 dan Tahun 2018 mencapai 5.284.

3. Sarana dan prasarana pengelolaan arsip di Balai Karantina Ikan Pengendalian Mutu dan Keamanan Hasil Perikanan Semarang bertambah menjadi lebih lengkap dan luas

\section{SARAN}

Dari kesimpulan di atas penelitian tersebut bisa untuk dijadikan referensi penulisan selanjutnya dalam topik yang sama serta dapat menampilkan data-data yng lebih lengkap lagi sehingga penelitian ini lebih bagus lagi, masukan dan saran membangun selalu kami harapkan untuk perbaikan penulisan selanjutnya. 


\section{UCAPAN TERIMA KASIH}

Ucapan terimakasih penulis sampaikan kepada :

1. Pimpinan Pembina Kearsipan di Unit Kearsipan Kementerian Kelautan dan Perikanan Republik Indonesia

2. Pimpinan di Balai Karantina Ikan Pengendalian Mutu dan Keamanan Hasil Perikanan Semarang

3. Teman-teman yang sudah banyak membantu memberikan data-data penyusunanan penulisan jurnal ini sehingga dapat merangkai jurnal ini dengan maksimal.

\section{DAFTAR PUSTAKA}

Agus Sugiarto dan Teguh Wahyono. (2005). Manajemen Kearsipan Modern dan Konvensional Berbasis Komputer. Yogyakarta : Grava Media

Amsyah, Zulkifli. 1996. Manajemen Kearsipan. Jakarta. PT. Gramedia Utama

Amsyah. Z. 2001. Manajemen Kearsipan. Jakarta. PT. Gramedia Pustaka Utama
Barthos, Basir. 2007. Manajemen Kearsipan. Jakarta : Bumi Aksara

Peraturan Menteri Pendayagunaan Aparatur Negara dan Reformasi Birokrasi Republik Indonesia Nomor 13 tahun 2016 Tentang Jabatan Fungsional Arsiparis dan Angka Kreditnya, pasal 1. Sumber Kumpulan Peraturan Tentang Jabatan Fungsional Arsiparis KKP

Peraturan Menteri Kelautan dan Perikanan Republik Indonesia Nomor 67/PERMEN-KP/2016, Tentang Kearsipan di Lingkungan Kemenerian Kelautan dan Perikanan

Sukoco, B..M. 2007. Manajemen Administrasi Perkantoran Modern. Jakarta : Erlangga

Undang-Undang Republik Indonesia No. 23 Tahun 2014 tentang Pemerintah Daerah

Wursanto. (2004). Kearsipan 1. Yogyakarta. Kanisius 